\title{
A hybrid Christian identity in Philippians 1:15-18
}

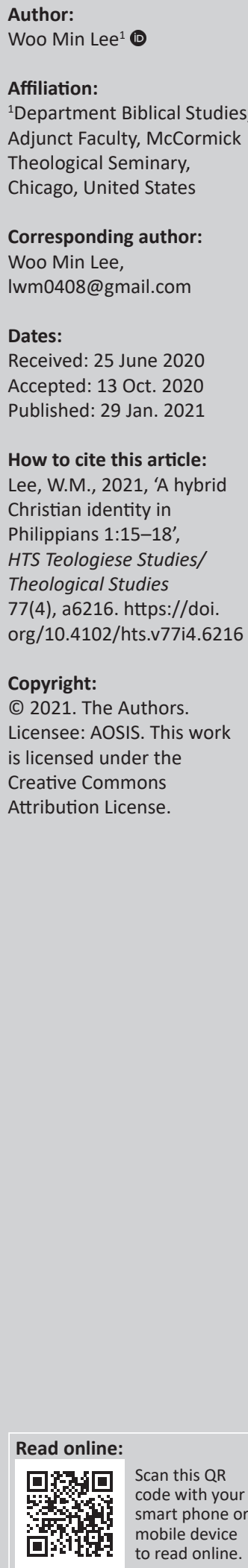

There have been various studies on the passage of Philippians 1:15-18 but there have been few studies on a hybrid aspect of Christian identity implicated in the passage. The aim of the study was to reveal a hybrid aspect of the passage. The socio-historical setting for the study was the Greco-Roman period. For this study, I employed rhetorical criticism, a sociolinguistic approach and an anthropological linguistic approach to the passage, as well as the analysis of the socio-historical and cultural background of the passage. As a result, I found that Paul, who retained his Jewish identity but embraced Christian identity, tried to suggest such a new kind of identity for the intended audience and their community. In this article, I argued that Paul as a hybrid personality urged the Christian community in Philippi to have distinguished Christian habitus and field in Philippians 1:15-18. In particular, Paul persuaded his intended audience or readers to acknowledge and accept even those preachers who had questionable intentions into their Christian community. Such an inclusive attitude was to make a clear distinction between the community and their traditional Greco-Roman socio-cultural background.

Contribution: The research on Philippians 1:15-18 reveals a hybrid aspect of Christian identity implicated in the passage. This research would contribute to the biblical studies of the Hervormde Teologiese Studies journal through its rhetorical, socio-linguistic and anthropological approach to the biblical passage of Philippians 1:15-18.

Keywords: Paul; Philippians; Christian; hybrid; habitus; field; community; identity.

\section{Introduction}

In Philippians 1:15-18, Paul, who had a hybrid identity, urged his intended audience to have a distinguished Christian identity in the Greco-Roman cultural and socio-historical context. In the passage, he writes to his intended audience or readers about his thoughts regarding the preachers with questionable intentions behind their proclamation of Christ. In particular, he suggests a Christian way of accepting those preachers within the Christian community. Furthermore, Paul declares that he would rejoice in the proclamation of Christ in every possible way. Whilst using the rhetorical structure and the words commonly used in Greco-Roman culture, he provides an unfamiliar concept of inclusive acknowledgement and acceptance of the questionable preachers in Christ.

In this article, the definition of the term 'hybrid' is based upon Bhabha (2006) who defines hybridity as 'the sign of the productivity of colonial power, its shifting forces and fixities; it is the name for the strategic reversal of the process of domination through disavowal' (p. 42). In particular, Bhabha (2000) describes that the 'vernacular cosmopolitans are compelled to make a tryst with cultural translations as an act of survival' (p. 139). Furthermore, they usually occupy 'between the lines' of dominant cultural practices, which can also be called as an 'in-between' space (Bhabha 2000:139).

Based upon Bhabha's concept of hybridity, Seesengood (2006:20-24) argues that Paul's identity was constructed to be hybrid. Along with his understanding of Paul's identity, I use the term, 'hybrid' or 'hybridity', to describe Paul's personality and Christian community that contain Jewish, Greco-Roman and Christian elements (eds. Werbner \& Modood 1997:1).

Regarding the understanding of the relationship between Paul's hybrid personality and his historical and socio-cultural context, Malina and Neyrey (1996:16) suggest that the first-century Mediterranean people were group-oriented and 'socially' minded people. They further argue that Paul, as a person from the Mediterranean society, was a typically group-oriented person (Malina \& Neyrey 1996:217). His personality as an apostle and a prophet was dependent upon 
his group including his ancestors, groups and God (Malina \& Neyrey 1996:217). Overall, Paul's personal identity was affected mainly by his in-group, which was later called as Christians.

On the contrary, Eisenbaum (2009:1-4) provides a different understanding of Paul's personality in her suggestion that Paul had a complex identity, which combined his ethnic identity and religious identity. Furthermore, she argues that Paul was a Jew and he maintained his identity as a Jew (Eisenbaum 2009:5). Reconsidering Bhabha's concept of hybridity and Seesengood's application, it is plausible that Paul did not totally leave or deny his innate Jewish identity. As Eisenbaum suggests, Paul became a Jewish Christfollower, which formed his hybrid identity in his historical and socio-cultural context of the first-century Mediterranean society.

The relationship or even contrast between Paul's hybrid identity and his social context can be understood in terms of habitus defined and described by Bourdieu (1977) as:

The habitus, the durably installed generative principle of regulated improvisations, produces practices, which tend to reproduce the regularities immanent in the objective conditions of the production of their generative principle, while adjusting to the demands inscribed as objective potentialities in the situation, as defined by the cognitive and motivating structures making up the habitus.

According to Dovey (2005:284), habitus is a way of knowing the world, a set of divisions of space and time, of people and things, which structure social practice (). Along with habitus, Bourdieu (1984:101) suggests that field can be defined as the place where habitus is practiced. It is a system of power relations based upon the unequal distribution of capital (Bourdieu 1991:57). Or, it is a social space with a structure to control resources including forms of capital, which can be cultural, social, economic and symbolic (Dovey 2005:285-288).

Firstly, this article explores Philippians 1:15-18 to reconstruct Paul's identity with a focus on the relationship amongst the text, its author, intended audience and socio-cultural context of the first-century Mediterranean society. For this goal, this study first considers the social and cultural background of Paul and of Philippian church community and the literary structure of Philippians 1:15-18. Understanding the situation of both parties can shed some light on the understanding of the field of Paul and the addressees of his letter. Then, this article analyses the rhetorical structure and the keywords of Philippians 1:15-18. It also investigates how the literary structure and the words employed by Paul were used in other contemporary texts.

Secondly, this article employs a socio-linguistic approach to Philippians 1:15-18 to explicate how Paul urged his intended audience to have an identity as a Christian community, which would be distinct from their Greco-Roman social context. Continued from the first section regarding the interrelatedness between the passage and its socio-cultural background, this section sets its focus on Paul's ideological aspect imbedded in the text. The use of language is deeply related to the dynamics amongst the members of the society. In particular, a language can be used as means to carry the ideology of the dominant level of the society. Therefore, the analysis of the passage from a socio-linguistic viewpoint shows what cultural aspect Paul tries to challenge or even change through his language in Philippians 1:15-18.

Thirdly, this article analyses Philippians 1:15-18 from an anthropological linguistic viewpoint to show that the passage distinguishes Paul and the Christian community from the outer society and culture. This section mainly considers the relationship amongst Paul, his intended audience in the passage and their social background. Through the analysis, it shows that Paul urges the Christian community to have their own ideology of the conflict between the positive group and the negative group, which is distinguished from the dominant perspective of their outer context. Furthermore, Paul would like to bring a change to the field of his contemporary society through his suggested Christian habitus and practice.

\section{Socio-cultural background and rhetorical criticism}

The epistle to Philippians seems to be written at a time when Paul was in prison and he was separated from the church at Philippi (Fitzgerald 1992:320). Philippians 1:12-26 is specifically concerned about his situation in prison in Rome or Ephesus (Reumann 2008:186). Schnelle (1998:130-133) suggests that Philippians was probably written in Rome about $60 \mathrm{CE}$. The population of Philippi at that time consisted of Greeks, Romans, native Thracians and foreigners (Koukouli-Chrysantaki 1998:22). The city was an agricultural Roman colony and many of the people lived in villages or the large farms scattered over the territory (Koukouli-Chrysantaki 1998:22).

Regarding the social structure of the city, Romans were the ruling class, and they were in charge of the administration of the colony (Koukouli-Chrysantaki 1998:23). The people including Roman, Greek and Thracian citizens, liberti, slaves and foreigners were organised in collegia, usually of a religious nature (Koukouli-Chrysantaki 1998:23). Latin was already the official language, but Greek was also used until the third or fourth century CE (Koukouli-Chrysantaki 1998:23). Although there is little accurately dated archaeological evidence about the cults in Philippi at that time, the old gods such as Apollo Comaeus and Artemis retained an important place in the city's religious life (Koukouli-Chrysantaki 1998:24). The cult of Dionysos was also considered as main religious practice in the city (Koukouli-Chrysantaki 1998:24). In Philippi, inhabitants worshipped not only the Greek pantheon but also Roman gods, local gods and foreign gods from Asia Minor and Egypt (Koukouli-Chrysantaki 1998:25). The cults of gods 
were mainly for a better life after death and they were popular in the city (Koukouli-Chrysantaki 1998:26).

In Philippians 1:12-26, Paul intensely used personal expression and he employed clear rhetorical patterns: reassurance and encouragement of followers, critique of the unworthy motives of others, philosophical reflection on the burdens and anticipation of his return to the Philippians (Osiek 2000:38). Philippians 1:12-14 reflects the situation in Rome in the early 60s CE (Fee 1999:60). Schnelle (2005:167) suggests that the Roman church had grown very quickly during the Neronian rule. Under Nero's rule, however, the church in Rome had begun to fall under suspicion (Tacitus 1906:304, 305). Fee (1999:60) suggests that this situation led the followers of Christ to be less evangelical than was usual for early Christians.

Concerning that situation of the church, Paul explains to the church at Philippi that the net effect of his imprisonment had led Roman Christians to have the courage to proclaim Christ in Rome (Fee 1999:60). In Philippians 1:15-18, Paul questions the motives of others but he embraces the outcome (Osiek 2000:38). Finally, he expresses his joy in Philippians. 1:18 (Osiek 2000:40, 41).

The quality of Paul's Greek writing implies that he read works written in Greek and he was familiar with the compositional and argumentative patterns in those works (Aune 2003:342). Paul may have had a basic Hellenistic education and was certainly familiar with rhetoric, which was popular at that time, although it is not clear to what extent he got formal education or how much he was exposed to the Greco-Roman culture of rhetorical theory and practice (Aune 2003:340). According to Acts 9, 22, 26, and Philippians 3:4-6, he was a Jew and a Pharisee (Aune 2003:342). He was born in Tarsus (Ac 9:11; 21:39; 22:3) and he was a citizen of that city (Aune 2003:342). After his encounter with Christ, he became a Jewish Christian and he defended and proclaimed Christianity in his writings.

Paul's familiarity with Greco-Roman rhetoric can be found in Philippians 1:15-18. Concerning the rhetorical structure of Philippians, there are two ways of analysis on Philippians 1:15-18 (Aune 2003:357). The first opinion suggests that the passage is categorised as narratio whilst the second one describes that it is considered as exordium in the whole structure of rhetoric in the letter to Philippians (Aune 2003:359)

Reumann (2008:188) points out that Philippians 1:12-18 has no Old Testament (OT) parallel or no early Christian liturgical tradition. Vocabulary including Christ (1:15) and preaching $(1: 17,18)$ is related to the word gospel $(1: 16)$, which is the key point of the passage (Reumann 2008:188). Therefore, Philippians 1:12-18 should be considered as a unified and self-enclosed subtext, focused on proclamation (Reumann 2008:188). The observation of Reumann on the passage can also be evidenced that Paul sets up his own thoughts on the proclamation of Christianity. Without any precedent parallel, Paul explicates the idea of the gospel in the epistle to the church at Philippi. He uses Greek vocabulary and rhetoric in Philippians 1:12-18 to show his idea to the Christian community at Philippi.

Philippians 1:15-18 has a chiastic structure and Paul tries to draw a picture of the identity of Christianity (Browning 1996:62). ${ }^{1}$ In the passage, he states that the gospel advances despite the kind of inner motivation the preachers have. He compares two groups of those who preach Christ. One group proclaims the gospel with ill will whilst the other does with goodwill. The rhetoric pattern of the passage can be analysed as $\mathrm{ABB}^{\prime} \mathrm{A}^{\prime}$ pattern (Fee 1999:60, 61):

A Some preach Christ because of envy and rivalry (v. 15)

B Others out of goodwill (v. 15)

B' The latter do so in love because they know my imprisonment is on behalf of the gospel (v. 16)

$\mathrm{A}^{\prime}$ The former proclaim Christ out of selfish ambition, not sincerely, supposing they are causing affliction in my bonds (v. 17)

The chiasmus can also be analysed as double chiasmus (ABB'A'ABBAA) (Reumann 2008:189):

$\begin{array}{lll}\text { v 15 } & \text { A envy } & \text { B goodwill } \\ \text { v 16-17 } & \text { B' love } & \text { A' self-interest } \\ \text { v 18a } & \text { A pretense } & \text { B truth } \\ \text { v 16-17 } & \begin{array}{l}\text { B because they know... } \\ \text { I am put here }\end{array} & \begin{array}{l}\text { A because they } \\ \text { suppose... to stir } \\ \text { up trouble }\end{array}\end{array}$

plus in $\mathrm{v} 17$ A not with a pure motivation

Comparing these two rhetorical chiastic structures suggested by Fee and Reumann, both of them show that Paul describes group A more fully than group B in the passage. Arranging two groups in parallel, Paul seems to show the polemic between the two groups more vividly. Fee (1999:61) suggests that the emphasis lies with the $\mathrm{A} / \mathrm{A}^{\prime}$ clauses because the group is dealt with more detail than group B/B'. Furthermore, the chiastic structure also seems to emphasise how much those two groups contrast to each other.

Along with the chiastic rhetoric structure, Paul employs contrasting words to the description of the groups $\mathrm{A} / \mathrm{A}^{\prime}$ and B/B'. In Philippians 1:15, Paul describes that some proclaim Christ from 'envy' and 'rivalry' whilst others from goodwill. The word 'envy' is $\varphi$ oóvo in Greek, and it can be found in classical sources (Hesiod, Opera et Dies 195-201, Theogony 383ff.) (Hesiod 2006:102-105, 34,35) and the papyri (Reumann 2008:177, 199, 200). It usually means 'envy', 'jealousy' or 'refusal from ill-will'. It was used widely in Greek society, and it was considered as being contrary to goodwill according 1.Chiasmus is a literary device used in rhetoric and in poetry to designate the inversion of an order of words, phrases or rhyming, which follow subsequently in the materia ('Chiasmus', Browning 1996:62). 
to Plutarch's treatise 'On Envy and Hatred' (Moralia 536E-538F = Loeb Classical Library 7:94-107) (Reumann 2008:177). Envy occurs towards the other person and its aim is to 'to reduce one's neighbour to equality with oneself' (Reumann 2008:177). Envy is to begrudge other's possession of some singular quality, object or relationship (eds. Pilch \& Malina 1993:55). A cause of envy is the limited nature of the quality, object or relationship in question and the social status of the possessor (eds. Pilch \& Malina 1993:55). Those who possess the quality usually stand out in social status or a certain social group (eds. Pilch \& Malina 1993:55, 56). Those who are envious tend to be negatively disposed towards those who have the limited quality and try to take that possession from them (eds. Pilch \& Malina 1993:56). With the negative tendency of envy, it was considered as malevolent and opposite to good (Reumann 2008:177). Its usage includes lawsuits, politics, strife in the city-state and division amongst countrymen (Reumann 2008:177-178).

The 'rivalry (strife)', which is ع́pıs in Greek, can be found in other Greek documents (Reumann 2008:178). Its meaning includes 'strife', 'quarrel', 'debate', 'contention', 'rivalry' and 'political or domestic discord'. It also can be found in Paul's vice lists ( $\operatorname{Rm} 1: 29 ; 1$ Cor 3:3; 2 Cor 12:20; Gal 5:20), whilst it cannot be found in OT or its related documents (Reumann 2008:178). The word was often personified in Greek documents such as in Homeric battle scenes (Il. 4:440-41) (Homer 1915:77, 78) or Hesiod (Theog. 225ff., the mother of battles) (Hesiod 2006:20, 21). According to them, हैpı stirred up the quarrel amongst gods and led to war (Reumann 2008:178). Its vicious characteristic to arouse conflict could be related to its use in New Testament documents (Reumann 2008:178). Paul also uses the word in his writing in Philippians $1: 15$ and his usage of हैpı contains a negative sense.

In the chiastic structure, the pair of $\varphi \theta$ óvo $\varsigma$ and ع̈pı are a

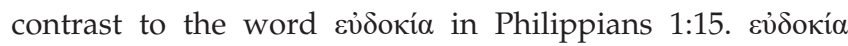
means 'state or condition of being kindly disposed, good will' and it is attributed to other group of Christians (Reumann 2008:179). Few of its examples can be found in other Greek documents (Theological Lexicon of the New Testament, vol. 2) (Spicq 1994:103 n 26), but some of them can be found in LXX (Ps 76:8b; 84:2; 105:4) and Synoptic Gospels (Mt 12:18; Mk 1:11; Lk 3:22; 12:32; Mt 17:5) (Reumann 2008:179). The word is generally related to the goodwill or the favour of God in Christian documents (Reumann 2008:179). Paul also employs the word to express God's good pleasure or will in his writing (Reumann 2008:179).

Paul's contrast between the preachers' group with questionable or even negative motives and the group with positive motives is continued in Philippians 1:16, where he provides readers with more detail of the latter. In the verse, Paul describes that they proclaim Christ out of love ( $\dot{\varepsilon} \xi \dot{\alpha} \gamma \alpha \dot{\alpha} \pi \eta \varsigma)$. The meaning of $\dot{\alpha} \gamma \alpha \dot{\alpha} \pi \eta$ includes 'love', brotherly love' and 'charity'. Reumann (2008:180) suggests that 'love', which is $\dot{\alpha} \gamma \alpha \dot{\pi} \eta$ in Greek, is human love on the part of Christian. Fee (1999:61) explains that the 'love' is love for
Paul and evangelism is expressed in terms of 'preaching Christ'. They understood that Paul was in prison for God, and they began to preach the gospel on behalf of Paul. In other words, they were on the same side with Paul and he described them with the word of positive sense. In this verse, he was a defender of the gospel under the rule of the empire (Fee 1999:61).

Philippians 1:16 seems to reflect Paul's understanding of his ordeal (Fee 1999:61). From the Roman point of view, Paul is on trial over a matter of the status of Christianity as religio licita [approved religion] in the Greco-Roman context, or of maiestas [treason] against Caesar because of the Christian confession of the 'lordship' of Jesus Christ (Fee 1999:61). From the viewpoint of Paul, the gospel itself is on trial and his imprisonment is for the defense of Gospel (Fee 1999:61, 62).

In Philippians 1:17, however, Paul describes other group in negative terms, which makes a sharp contrast to the group described in Philippians 1:16. According to Philippians 1:17, the other group proclaims Christ out of selfish interest. The phrase $\dot{\varepsilon} \xi \hat{\varepsilon} \rho 1 \theta$ cías in Philippians 1:17 is a parallel to $\dot{\varepsilon} \xi \dot{\alpha} \gamma \alpha \dot{\pi} \pi \eta \varsigma$ in Philippians 1:16. ¿̇pı $\theta$ cí $\alpha$ usually means 'selfish'. Reumann (2008:180) describes that غ́pı $\theta$ cía can be related to ع̈pıs, even though each may have a different sense. 'Selfish' sense of the

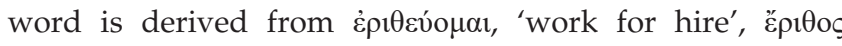
'worker for hire (mercenary)' (Reumann 2008:182). Laboring for one's own interests rather than devotion to public service can lead to have 'selfishness' in 'spı $\theta$ cía (Reumann 2008:182).

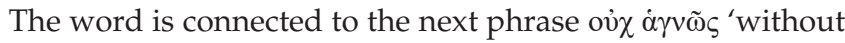
a pure motive'. According to the parallel of the chiastic structure, Paul considers those who had selfish interest in preaching Christ as having impure intention. Consequently, those preachers are in contrast to those who preach Christ out of love as described in Philippians 1:16.

Furthermore, the group of self-interest is to cause or rouse affliction or suffering ( $\theta \lambda \tilde{i} \psi 1 \varsigma)$ of Paul (Phil 1:17). The negative attribute of the group is finally described vividly in relationship with Paul. The Greek word $\theta \lambda \tilde{i} \psi 1 s$ means 'oppression, affliction, tribulation, (1) from outward circumstances, or (2) mental and spiritual affliction of mind' (Reumann 2008:182, 183). Here, it is used to describe that Paul experiences more than mental affliction whilst in prison (Reumann 2008:183).

Finally, Paul combines those two contradicting groups under the proclamation of Christ in Philippians 1:18. After the sharp polemic between those two groups in Philippians 1:15-17, Paul resolves the contradiction in Philippians 1:18. In this verse, he still employs contradicting words to describe those two groups. For the group with questionable motives, he uses $\pi \rho$ ó $\alpha \alpha \sigma \varsigma \varsigma$ whilst he employs $\dot{\alpha} \lambda \dot{\eta} \theta \varepsilon 1 \alpha$ for the group described in positive terms. $\pi \rho \varphi \alpha \sigma \iota_{\varsigma}$ is a classical Greek term, which can be found in the papyri (Moulton \& Milligan 1914:555) and also medical documents (Theological Lexicon of the New Testament, vol. 3) (Spicq 1994:204 n 2, 206 n 10). It usually 
means 'falsely alleged motive, pretext, ostensible reason, excuse'. Meanwhile, Paul describes that other group proclaims Christ in truth $(\dot{\alpha} \lambda \dot{\eta} \theta \varepsilon 1 \alpha)$. The word is found 47 times in the Pauline corpus and the meaning is 'truthfulness (1 Cor 5:8), truth (Gal 2:5; 5:7, in opposition to falsehood), reality (Rom 2:2, in contrast to appearance)' (Reumann 2008:184).

Reumann (2008:202-206) suggests various possibilities for the identity of the negative group. This group is a rival group to Paul, and they are opposed against Paul and his positive group of preachers. Fee (1999:62) explains that the keywords for the negative group would be épı sand غ̇pı $\theta \varepsilon i ́ \alpha$. Even though Paul considers the group as negative, he concedes that the group preaches Christ as Paul does. In that manner, it is possible to think that the negative group would be fellow believers, even though they have personal animosity towards Paul (Fee 1999:62).

In Philippians 1:18, Paul concludes that the focus should be set on whether Christ is proclaimed or not. He claims that even the negative group also contributes to the proclamation of Christ. Consequently, the negative group can be also considered as positive in a big picture of the evangelism of Christianity. Along with the conciliation of the two contradicting groups, Paul says that he will rejoice in Philippians 1:18.

The reason why Paul writes his passage to the church at Philippi could be related to the situation of internal unrest in the church community (Fee 1999:63). Recognising the problematic situation of the community, he tries to suggest reconciliation or mutual acceptance of the two conflicting sides to proclaim Christ. If internal conflict developed, it would lead to damage the foundation of the church community. Therefore, he describes his open mind towards his rival or hostile group for the evangelism.

Finally, Paul expresses his joy in the proclamation of Christ. Even though there is a conflict between two groups of preachers, it does not prevent him from rejoicing. Paul asserts that even a negative group as having a positive factor anyhow, they proclaim Christ. The fact that Christ is proclaimed makes Paul rejoice. Fee (1999:64) suggests that Philippians 1:1-18 encourages the Philippians to rejoice with him in the difficult situation of conflict at church.

\section{A socio-linguistic approach}

As mentioned in this article, the words and the literary structure employed in Philippians 1:15-18 reflect the Greek culture where Paul was situated. Regarding the relationship between language and society, one of the main arguments of socio-linguistic theories is that language can be considered as an aspect of its society (Fairclough 2001:23). Language phenomena are social in the sense that people use language within their social context. In other words, when people use language, they usually follow the social convention of language use. By the convention of language, they can make their communication understood in their society. They select words and syntactic structure based on their social convention. Therefore, language itself can be considered as a social phenomenon. In the case of Paul's writing and its contemporary social context, it is evident that he uses the Greek words and rhetoric of chiasmus according to his own social convention of Greek Roman culture.

Based upon a socio-linguistic theory about the interrelatedness between discourse and its social context, the analysis of Philippians 1:15-18 would reveal its surrounding social context. As a social process, social conditions have influence on usage and structure of language and language has socially determined factors (Fairclough 2001:24, 25). Fairclough (2001:25) describes that the text reflects social condition. Text is produced by interaction between members of society and the interaction is governed by social conditions. Social conditions function as a context for the production of interaction and interaction affects the production of text. Therefore, the interpretation of a text should reflect the social context surrounding the text. In that sense, the word and the rhetorical structure of Philippians 1:15-18 reflects the presiding Greek culture at that time.

Through the usage of the familiar words or the rhetoric expressions, Paul tries to help his intended audience or readers to understand what he means in his letter. The relationship between social classes has influence on all parts of society (Fairclough 2001:32). The dominant class has social power and they control the entire society. Fairclough (2001:33) explains that language as social practice reflects the social power of the society. In particular, it reflects the ideology of the dominant class of the society. The ideology does not show up on the face level of the language. Rather, it is naturalised as common sense within the language. Consequently, it is not easy for people to recognise the ideology embedded in discourse. With the wide use of language that contains the dominant ideology in the society, the dominant class of the society can maintain their power. This theory can be applied to the case of Paul in Philippians 1:15-18. Paul uses socially acceptable and familiar vocabulary and rhetoric. Through the usage of the familiar language, the intended readers or audience, who are also the members of the Roman society, could understand what Paul intends to deliver.

As in other Greek documents, Paul uses negative and positive terms in a negative sense in Philippians 1:15-18. Paul does not change the semantic domains of the words at the level of vocabulary. Paul seems to simply employ those words as their original meanings and usage in other Greek documents to write his letter to the church at Philippi. He also employs rhetoric without changing its structure. The chiastic structure can be found in other Greek documents. Therefore, Paul seems to accept the writing convention of his cultural and social context.

With the socially acceptable and familiar words and literary structure, however, Paul tries to provide a totally new 
perspective distinct from his social context. According to Fairclough (2001:34), critical analysis of the discourse can cause social change. He claims that the power relationship between the dominant bloc and the dominated class is not static but dynamic (Fairclough 2001:34). The dominant class tries to maintain its social power and the dominated classes challenge the dominant bloc for social power. In the power struggle, critical analysis of discourse is critical, because it can reveal the ideology of the dominant class. If the dominated class recognises the hidden ideology of the dominant class through the analysis of the language, they would be able to get some evidence or proof to shake the social structure. In the case of Philippians 1:15-18, Paul seems to simply accept the social convention of a polar concept of negative and positive. Negative characteristic should be avoided, and positive characteristic should be accepted based on the usage of the word in Greek documents. However, Paul upsets the common sense of the polarity concept in Philippians 1:18. In Philippians 1:15-17, he contrasts the negative group and the positive group by his usage of vocabulary and the chiastic structure. The contrasting concept between the negative side and the positive side can be considered as being based on the Greek culture. In Philippians 1:18, through the reconciliation or unification of the contrasting groups with Christian insight, he reshapes the prevailing polar concept of his social and cultural context.

The key concepts found in the passage of Philippians 1:15-18 can be also found in other texts including the Chremonidean decree and Paul's other texts such as Romans and 1 Corinthians. In other words, Paul's insights and thoughts came from his socio-cultural background and he developed what he received from his social context. Paul's reconciliation of conflicting polarity can be analogous to the book of Romans (Jewett 1994:129, 130, 139-140, 632, 840-841, 905). Schnelle (1998:109) suggests that Paul wrote Romans in the spring of $56 \mathrm{CE}$. He also suggests that Philippians was probably written in Rome about 60 CE (Schnelle 1998:130-133). Regarding the analogy of Philippians 1:15-18 to Romans, it seems to be possible that Paul is giving the Philippians an example of harmony within the church based on the conflict he described earlier in Romans. In Philippians 1:15-18, he does not directly state that such a kind of conflict is actually occurring in Philippi. In Romans 1:14, Paul claims that his calling is both for Greeks and for 'barbarians', who are the Gentiles. Through this statement, he eliminates the polar opposites of Roman virtues (Jewett 1994:131). His reconciliatory attitude is clearly stated in Romans 1:16 (Jewett 1994:139). In this verse, Paul claims that the gospel is for salvation to everyone who has faith, to the Jew and also to the Greeks. He does not distinguish the Greeks, the strong or honour side, from the Jews, the weak or shame side (Jewett 1994:139). Instead, he insists that the gospel of Christ eliminates the honour and shame distinction (Jewett 1994:139, 140). All of the Christian groups in Rome have equal access to faith of Christ (Jewett 1994:140). Romans 10:12 reinforces Paul's assertion that Christ has erased the boundaries of honour and shame and the gospel has eliminated the prejudicial boundaries between social groups (Jewett 1994:632). Romans 14:3 also can be related to Paul's reconciliatory attitude and his even-handedness in the sense that it concerns about the equal treatment of the weak and the strong (Jewett 1994:840). In this verse, Paul asserts that God welcomes sinners without regard to their prior status or performance, and God gives his grant to sinners and enemies (Jewett 1994:840, 841). Romans 15:14 is another verse to show Paul's mutuality that is a countercultural strategy to reverse the hierarchical and elitist premises of the Mediterranean world (Jewett 1994:905). Jewett notes that even Philodemus, whose writings come closest to Pauline mutuality, would not be prepared to assign equal roles to both the 'weak' and the 'strong', or to extend mutuality to 'barbarians' and 'uneducated' (Glad 1995:124-132; Jewett 1994:905).

Paul's reconciliation in Philippians 1:15-18 does not just provide only a theologically bigger picture but also a socially and ideologically new picture for the Christian community as well. Even though he was situated in the social context of Greco-Roman culture, he did not simply accept the dominant culture as it was. Rather, he urges his intended audience to establish a new paradigm of reconciliation in Christianity. He does not antagonise the negative group who proclaim Christ with questionable motives. Rather, he tries to accept them as having a positive role to proclaim Christ. He seems to deconstruct social and cultural conventions to reconstruct some aspect of Christian paradigm of thought. His strategy to deal with the Christian missionaries with ill motives is not to criticise and expel them, but to accept them as fellow preachers. His strategy is his personal decision or thought, but he recommends his way of thinking to the church members at Philippi. He also wants them to change their way of thinking. In that sense, he seems to reveal some ideological aspect of Christianity to his fellow believers.

Philippians 1:15-18 does not seem to mean that Paul tries to upset or deny the entire social system of Roman Empire to get political power. Paul's idea of Christianity does not result from any political struggle or conflict with the dominant political group of Roman Empire. Rather, Paul seems to deal with the problem inside the church community. Osiek (2000:40) suggests that Paul did not get along with everyone in the churches. To resolve the internal conflict, Paul puts emphasis on the unification of the preachers of the gospel under Christ rather than any conflict or struggle among them. His idea to identify the Christian community as having reconciliatory and unified value can be distinguished from polarity and conflict in power struggles and conquest, which can be found in the Roman Empire.

Paul's reconciliatory attitude can be compared with ó $\mu$ óvor $\alpha$ in the Chremonidean decree (Erskine 1990:90-95). In the decree, it was for the internal harmony and it was used with $\dot{\varepsilon} \lambda \varepsilon v \theta \varepsilon p i \alpha$ in the decree (Erskine 1990:94). For the true ó $\mu$ óvor $\alpha$, there had to be true $\varepsilon \dot{\lambda} \varepsilon v \theta \varepsilon \varepsilon \rho i \alpha$ (Erskine 1990:94). The difference 
between Paul's reconciliation and ópóvor $\alpha$ in the decree is that Paul's reconciliation aims the proclamation of the gospel, whilst ónóvor $\alpha$ in the decree is political propaganda for the anti-Macedonian alliance between Athens and Sparta (Erskine 1990:95). Even though there is similarity between Paul's writing and the decree, Paul reshapes the concept of harmony with a Christian insight.

Paul's reshaping the concept of harmony or reconciliation in Philippians 1:15-18 can be related to 1 Corinthians (Mitchell 1991:180-182). Mitchell (1991:181) explains that Paul uses part of common topoi used to promote social and political unity in Greco-Roman society. According to her, Paul does not simply use political topoi, but he rather adapts and integrates them into his overall argument for unity with his Christian insights (Mitchell 1991:181,182). Likewise, Paul applies Greco-Roman rhetoric to reshape the concept of reconciliation or harmony with his Christian insight in Philippians 1:15-18.

\section{An anthropological linguistic approach}

It is possible that Paul's remark regarding the social and cultural context of the church into Philippians 1:15-18 was considered shocking by the church members at Philippi. In the field of the Roman Empire, the unity, harmony or maintenance of the society can be achieved by the elimination of the opposite faction. In this social setting, most of the members of the society would follow the convention of such a social practice. However, Paul betrays the social convention of his field and reveals a different aspect of unity: unity by reconciliation between different or even conflicting groups for the proclamation of the gospel. Therefore, his argument in Philippians 1:18 would be surprising to the church at Philippi.

The reason for Paul's argument of unity through reconciliation can be found in Paul's habitus. As mentioned in this article, habitus tends to be formed based on its field, its social context. For Paul who was a Hellenist Jew, his habitus was based on his social context of Hellenism.

However, Christ metamorphosed him into a Christian (2 Cor 3:18), which led his habitus to a Christian worldview. As a result, he got habitus which was different from his previous one. Philippians 1:15-18 is a good example of his changed view of the world as a Christian. He does not follow the social conventions of Hellenism or the Roman Empire on the concept of polarities (Jewett 1994:88, 130, 632, 905). Even though he still discerns the negative and the positive factions, he does not eliminate the preachers with questionable motives, nor he simply calls for political unity. Instead, he tries to acknowledge them for the proclamation of Christ.

Through his writing of Philippians 1:15-18, Paul also seems to recommend the church community at Philippi to take his view of reconciliation. He explains how to accept their conflicting members and to be united in Christ to the community members. In other words, he introduces Christian habitus to the members of the church. It is not certain that the church members actually accepted Paul's worldview, but the passage does suggest that Paul modeled this type of habitus to other community members.

Furthermore, Philippians 1:15-18 seems to identify the Christian community based on Paul's experience and situation in Rome. Paul has his own habitus that does not follow the field of his social context of Roman Empire. He emphasises unity through Christian reconciliation rather than the struggle, strife or political unity of factionalism. With that distinction, he shows his own broadened identity as a Christian. He also suggests his habitus of largeness of heart as a Christian to the members of the church. If the members of the church accept his suggestion for a different and broadened habitus, the church community at large would form its own field within the church community at Philippi. Even though the church and its members are situated in the larger social context of the Roman Empire, they would form their own inner social structure of Christian community. Finally, they would achieve their own identity as Christian community, which can be distinguished from other communities or societies. $^{2}$

\section{Conclusion}

The main issue that Paul deals with in Philippians 1:15-18 is the proclamation of Christ. Writing this passage to the church at Philippi, Paul reveals his identity as a Christian and also his understanding of the ideal Christian community. In the passage, Paul employs Greek words and a chiastic structure for his argument so that it might be well understood by the church members at Philippi. His argument about the proclamation of Christ reveals that he already knows a group of preachers who have questionable motives in the church community. He writes this letter to urge his intended readers to accept those preachers in their Christian community for the proclamation of Christ.

Along with the theological issue, the passage reveals some aspects of Paul's complicated identity. The usage of Greek words and chiastic rhetoric structure shows that Paul had background knowledge of Greek culture and education. Considering Acts 9:1-22; 22:4-19; 26:9-15 and Philippians 3:4-6, he also had a Jewish background and Roman citizenship in Tarsus, a city in Cilicia. In short, his personality seems to be a mixture of various backgrounds.

Paul finally added a Christian element to his Hellenistic and Jewish identity. He was situated between Jewish tradition and Greco-Roman tradition. With the experience of an encounter with Christ, he newly gained his identity

2 According to Udo Schnelle 1 Corinthians describes that Paul developed and proticed a new unich practiced a new universal identity concept: 'being in Christ', which transcends all traditional religious privileges. The new not integrable into the Jewish and Greco-Roman identity structures and consequently led to the formation of early Christianity as an independent movement (Schnelle 2005:170). See also, Theissen (1999:90ff.). 
as a Christian. His identity as a Christian was a new kind that was different from his previous habitus based on his background culture of Hellenism.

Paul's Christian hybrid personality is reinforced in his argument on questionable preachers of the gospel in Philippians 1:15-18. His acceptance and acknowledgement of the preachers with his Christian insight is different from the conventional perception of Roman society. In that sense, the passage reveals some aspect of disparity between Paul and his social context. Even though Paul is situated in the social context of Greco-Roman culture, his habitus does not follow the social convention. Even though some gospel preachers may have wrong intentions and even oppose Paul, they do proclaim Christ. Therefore, Paul wants to accept them into the Christian community for the proclamation of the gospel. His Christian way of thinking which establishes a different paradigm from the outer Greco-Roman context also can be found in Philippians 4:10-20 about patronage and friendship. ${ }^{3}$ His personality was formed based on his social background but, with his Christian identity, he gained a different habitus from his previous one.

Paul's hybrid habitus as a Christian in Philippians 1:15-28 also functions as an impetus for the church at Philippi to change the habitus of the community members. Paul reshapes the conventional concept of struggle between contrasting groups and political unity through the usage of familiar Greek words and rhetoric structure. He urges the church at Philippi to add a Christian insight into their habitus of GrecoRoman or Hellenistic context as he did. If the community members achieve such a hybrid habitus, then the community will hopefully form a new kind of field that is also a hybrid form of Greco-Roman context and Christian belief. In conclusion, with a new habitus as a hybrid Christian, Paul adapts Greco-Roman rhetoric and reshapes the concept of reconciliation and harmony for unity with a Christian insight. He describes how to resolve the conflict between contrasting groups and achieve unity for the proclamation of Christ. His Christian way of unification also motivates the church members at Philippi to reshape the concept of power struggle and political unity in the dominant Greco-Roman cultural and social context and to realise a unified hybrid Christian community in Christ.

\section{Acknowledgements}

I would like to express my gratitude to Dr. David Balch who provided insightful comments on my initial draft at Graduate Theological Union in 2009. His feedback and suggestions were critical in developing my manuscript, though I am solely responsible for any shortcomings.

\section{Competing interests}

The author has declared that no competing interest exists.

3. Reumann describes that Paul suggests different views and practices of patronage and friendship in Philippians 4:10-20. In the passage, Paul reshapes Greco-Roman
friendship towards Christian koinōnia by insistence on God (See Reumann friendship towards Christian koinōnia by insis
2008:679-685, 692-693, 695-699, 704-706, 722).

\section{Author's contributions}

W.M.L. is the sole author of this research article.

\section{Ethical considerations}

This article followed all ethical standards for a research without direct contact with human or animal subjects.

\section{Funding information}

This research received no specific grant from any funding agency in the public, commercial or not-for-profit sectors.

\section{Data availability}

Data sharing is not applicable to this article as no new data were created or analysed in this study.

\section{Disclaimer}

The views and opinions expressed in this article are those of the author and do not necessarily reflect the official policy or position of any affiliated agency of the author.

\section{References}

Aune, D.E. (ed.), 2003, The Westminster dictionary of New Testament and early Christian literature and rhetoric, 1st edn., Westminster John Knox Press, Louisville, KY.

Bhabha, H., 2000, 'The Vernacular Cosmopolitan', in F. Dennis \& N. Khan (eds.), 2000, Voices of the crossing, pp. 133-142, Serpent's Tail, London.

Bhabha, H., 2006, 'Signs taken for wonders', in B. Ashcroft, G. Griffiths \& H. Tiffin (eds.), The post-colonial studies reader, 2nd edn., pp. 38-43, Routledge, London.

Bourdieu, P., 1977, Outline of a theory of practice, transl. R. Nice, Cambridge Studies in Social and Cultural Anthropology 16, Cambridge University Press, Cambridge.

Bourdieu, P., 1984, Distinction: A social critique of the judgement of taste, Harvard University Press, Cambridge, MA.

Bourdieu, P., 1991, Language and symbolic power, in J.B. Thompson (ed.), transl. G. Raymond \& M. Adamson, Harvard University Press, Cambridge, MA.

Browning, W.R.F., 1996, A dictionary of the Bible, Oxford [England], New York, NY.

Dovey, K., 2005, 'The silent complicity of architecture', in J. Hillier \& E. Rooksby (eds.), Habitus: A sense of place, pp. 282-296, Ashgate Publishing Limited, Aldershot.

Eisenbaum, P.M., 2009, Paul was not a Christian: The original message of a misunderstood apostle, 1st edn., HarperOne, New York, NY.

Erskine, A., 1991, The hellenistic stoa: Political thought and action, Duckworth, London. Fairclough, N., 2001, Language and power, 2nd edn., Longman, Harlow.

Fee, G.D., 1999, Philippians, The IVP New Testament commentary series 11, InterVarsity Press, Downers Grove, IL.

Fitzgerald, J.T., 1992, 'Philippians, Epistle to the,' in D.N. Freedman (ed.), The anchor bible dictionary, vol. 5, 1st edn., pp. 318-326, Doubleday, New York.

Glad, C.E., 1995, Paul and Philodemus: Adaptability in Epicurean and early Christian Psychagogy, E.J. Brill, Leiden.

Hesiod, 2006, Hesiod, in G.W. Most (ed.). transl. G.W. Most, The Loeb classical library 57, 503, Harvard University Press, Cambridge, MA.

Homer, 1915, The iliad of Homer, transl. A. Lang, Walter Leaf, and Ernest Myers, Macmillan, New York.

Jewett, R., 1994, Romans, Abingdon Press, Nashville, TN.

Koukouli-Chrysantaki, C., 1998, 'Colonia Iulia Augusta Philippensis', in C. Bakirtzes \& H. Koester (eds.), Philippi at the time of Paul and after his death, pp. 5-35, Trinity Press International, Harrisburg, PA.

Malina, B.J. \& Neyrey, J.H., 1996, Portraits of Paul: An archaeology of ancient personality, 1st edn., Westminster John Knox Press, Louisville, KY.

Mitchell, M.M., 1991, Paul and the Rhetoric of reconciliation: An exegetical investigation of the language and composition of 1 Corinthians, J.C.B. Mohr (Paul Siebeck), Tübingen.

Moulton, J.H. \& Milligan, G., 1914, The vocabulary of the Greek Testament: Illustrated from the Papyri and other non-literary sources, Hodder and Stoughton, London.

Osiek, C., 2000, Philippians, Philemon, Abingdon New Testament commentaries, Abingdon Press, Nashville, TN. 
Pilch, J.J. \& Malina, B.J. (eds.), 1993, Biblical social values and their meaning: A handbook, Hendrickson Publishers, Peabody, MA.

Reumann, J.H.P., 2008, Philippians: A new translation, Yale University Press New Haven, CT.

Schnelle, U., 1998, The history and theology of the New Testament writings, SCM Press Ltd., London.

Schnelle, U., 2005, Apostle Paul: His life and theology, Baker Academic, Grand Rapids, MI Seesengood, R., 2006, Competing identities: The athlete and the gladiator in early Christianity, T \& T Clark, New York, NY.
Spicq, C., 1994, Theological Lexicon of the New Testament, transl. J.D. Ernest, Hendrickson, Peabody, MA.

Tacitus, C., 1906, Annals of Tacitus, transl. A.J. Church \& W.J. Brodribb, Macmillan and Co., Limited, New York.

Theissen, G., 1999, 'Die urchristliche Taufe und die soziale Konstruktion des neuen Menschen', in J. Assmann \& G.G. Stroumsa (eds.), 1999, Transformations of the Inner Self in Ancient Religions, pp. 87-114, Brill, Leiden.

Werbner, P. \& Modood, T. (eds.), 1997, Debating cultural hybridity: Multi-cultural identities and the politics of anti-Racism, Zed Books, London. 